\title{
Accounting Software in Computerized Business Environment and Quality of Corporate Reporting
}

\author{
Omotilewa Oluwatoyin Olufemi ${ }^{1}$, Adegbie Folajimi Festus ${ }^{1}$, Adesola Munir Adekunle ${ }^{2}$ \\ ${ }^{1}$ Department of Accounting, School of Management Science, Babcock University, Ilishan Remo, Nigeria \\ ${ }^{2}$ Department of Banking and Finance, School of Business and Management Studies, Moshood Abiola Polytechnic, Abeokuta, Nigeria
}

\section{Email address:}

olufemiomotilewa@gmail.com (O. O. Olufemi), adegbief@babcock.edu.ng (A. F. Festus), Adesolama2019@gmail.com (A. M. Adekunle)

${ }^{*}$ Corresponding author

\section{To cite this article:}

Omotilewa Oluwatoyin Olufemi, Adegbie Folajimi Festus, Adesola Munir Adekunle. Accounting Software in Computerized Business Environment and Quality of Corporate Reporting. Journal of Finance and Accounting. Vol. 9, No. 3, 2021, pp. 101-110. doi: $10.11648 /$ j.jfa.20210903.16

Received: April 22, 2021; Accepted: May 29, 2021; Published: June 21, 2021

\begin{abstract}
The basic objective of financial reporting is provision of information useful for assessing a company performance and prospect. Low quality financial reporting contains inaccurate, misleading information that may result in losses and reduced confidence in corporate governance mechanism. Emerging globalization requires business entities to develop means of processing financial information accurately and speedily for users decision making. Therefore, this study was conducted to find out the effect of accounting software on the quality of corporate reporting. The study adopted cross-sectional survey research design and used structured questionnaire to collect primary data. The research instrument was validated using Cronbach Alpha to test the reliability of the instrument which showed coefficient of 0.704 for accounting information system and 0.806 for corporate reporting. The data collected were analyzed using descriptive and inferential statistics. The result of multiple regression analysis of hypotheses 1 showed that accounting software has a positive significantly effect on the reliability of corporate reporting $\left(R=0.594\right.$, Adj. $\left.R^{2}=0.627, F(3,485)=208.685, p=0.000<0.05\right)$ while the result of hypothesis II showed that accounting software has a positive significant effect on the accuracy of corporate reporting with a efficient of multiple correlation $\left(\mathrm{R}=0.629\right.$, Adj. $\left.\mathrm{R}^{2}=0.390, \mathrm{~F}(3,485)=80.180, \mathrm{p}=0.000<0.05\right)$. The study concluded that accounting software are effective in gathering and processing data and information to produce quality corporate reports. The study recommended that accounting software should be made more users friendly since it provides easier environment for businesses to manage financial reporting procedures and processing.
\end{abstract}

Keywords: Accounting Software, Business Entity, Computerized Information, Corporate Reporting, Quality

\section{Introduction}

Business entities employ financial reports to account for the results of their operations and use of resources obtain from the environment. The reports shape the decision making process of the many stakeholders associated with the entities [30]. The speed of change daily experienced in business value chain activities due to effects of globalization requires business entities to develop information system that have the speed and efficiency capable of delivering timely, accurate and reliable business information to guide decision making [52]. An Information system is the combination of various parts or sub systems which provides the vital Information needed by an entity for harnessing its resources and activities for improved decision making [23]. Any business entity that aims to achieve a continuous and sustained cutting edge financial information processing, communication and dissemination would require the adoption of information strategies of computerized accounting information system, tailored towards gaining efficiency and sustained business processes [21]. A computerized accounting information system consists of logical and physical objects, data, software, hardware policies, processes, skills sets and responsibilities, all interacting to shape the capabilities of an entity [17]. The systems record accounting transactions, using a computer and accounting software packages. It is a database oriented applications in which the transaction data of an entity are 
stored in a well organized database.

The application of computerized accounting information system has led to increasing need for accounting software technologies in order to ensure effectiveness of operations and improvement in decision making process and growth [49]. The application of information technologies and accounting software has brought improvement to the quality of financial reporting of entities as a result of accuracy of data and reduction in time used by entities to prepare and present their financial statement $([60,38])$. Furthermore, accounting information systems contribute to the overall functionality of accounting process by increasing the speed and accuracy of processing, and production of high quality financial report [63]. This is in addition to managers use of the systems to control business economic and financial resources [31] and its application to shore up the internal control system of organization at all times [12]. Thus the use of information communication technology has led to enhance organization performance and reliability of accounting information. ([23, 47]).

Corporate reporting and accounting functions of a business entity expand as the business grows, acquires new customers, entered new markets, all leading to increase in volume of accounting transactions and increase in exposure of information to errors and possible abuse due to complexity of the accounting system [67], Computerized information processing system present the risk of improper human intervention with computer programs and computer files, which may lead to tempering with computer based records with sole aim of deliberate falsification of accounting information and distortion of information essential for decision making. In addition, there is the challenge of separating accounting functions from operations by users. Accounting software is designed to support daily operations through data collation, data maintenance and data control to facilitate processing of financial information to improve internal operation and financial reporting [68]. Thus, whenever operation data are mixed with data for accounting software, there is the likelihood of inaccurate and incomplete financial reporting processing which can lead to misleading financial report. The overall effects of these is diminution of the value relevance of information contained in the financial reports, which can lead to sub-optimal investments decisions and loss of financial resources to investors and reduction in the value of a business entity [40].

In the light of the above, this paper sought to investigate whether accounting software are effective to gather and process data and information to produce quality corporate report. The objectives include to determine whether the use of accounting software affect the reliability of information in corporate reporting; and examine whether accounting software affect the accuracy of corporate reporting. The following hypotheses were tested in this study.

$\mathrm{Ho}_{1}$ : Accounting software does not significantly affect the reliability of corporate reporting.

$\mathrm{Ho}_{2}$ : Accounting software does not significantly affect the accuracy of corporate reporting.

\section{Literature Review}

\subsection{Conceptual Review}

\subsubsection{Accounting Software}

Accounting Information systems is a combination of computer software and hardware assembled for gathering and processing transaction data to generate accounting information ([41, 58]). Accounting Software component of computerized accounting information systems are critical to the generation of high quality accounting information on a timely basis, and its communication to the decision makers in the required format. A computerized accounting information system are dependent on software packages written on accounting principles and procedures and business logic, which enables the systems to carry out accounting functions automatically [32]. The software component of accounting system allows for a seamless processing activity and is imbibed with the capacity to validate data, records transactions, update accounts, and reconcile ledgers and accounts without human intervention $([10,35])$ with high-speed and accuracy.

The critical nature of accounting software and its importance is underscored by the fact that part of the structural characteristics of computerized accounting system; internal controls, automated data processing, relational database and automated reporting are synthesized within the framework of the accounting software framework, in a logically organized form in way to enhanced the performance and reliability of the system [48].

The need for accounting software became imperative due to the growing complexity of organizations accounting transactions and operations, vulnerability to errors and the need to produce reliable report for effective decision making [67].

There are so many types of accounting software; categorized as spreadsheet, enterprise resource planning, commercially available software and custom accounting software as the major types of accounting software [3]. The software are available to perform different accounting tasks for the organizations and are equipped with different features and processing capabilities. Software performance can be measured using such criteria as net promoter score, customer lifetime value customer acquisition cost, customer churn rate, monthly recurring revenue end average revenue per customer [11].

\subsubsection{Corporate Reporting}

Financial reporting is the process of reporting financial activities of a business on a formal way. It is considered as an essential resource for any market participation it also reduces the mystery and conflict in opinion between all interested users [24]. The essential principle (qualitative characteristics of assessing the financial reporting is related to the faithfulness of the objectives and quality of information contained in an entity financial reports [33]. The qualitative characteristics do allow for enhanced assessment of the usefulness of financial reports, which leads to high level of quality. The quality of corporate reporting is found dependent upon the value of accounting reporting which is dependent on the information system employed. High quality corporate reporting is required to assist 
users in making investment decisions and to enhance market efficiency [29]. The higher the quality of corporate reporting the more significant will be the benefits accruable to investors and users of the report. The quality of corporate reporting is viewed as a broad concept which not only cover financial information, it also includes other non-financial information necessarily useful for making decision.

The accounting information system should produce relevant reliable information [33]. The usage of appropriate information technology is essential to the accounting information system because of all the supports to accounting information system in order to generate required information is a short period of time. Information technology has a considerable influence on the accounting information system from the perspectives of operating, preparing, processing presents and develop the accounting information. Thus this significantly helps to support timelines as a qualitative characteristic of financial information which results in increasing financial reporting quality, and also supporting the quality of accuracy by using effective information technology [33], Thus, financial reports are required to be faithfully represented, comparable, verifiable, timely and understandable, in order that the reports will be transparent, and not containing misleading information, and will be precise and predictable as indicators of high financial reporting quality [22].

\subsubsection{Accuracy}

Accurate financial reporting is the tendency of financial reports to state the true position of the profitability, asset condition, bad debts provisions and other events concisely [1]. Accurate financial reporting forms the basis for the evaluation of a company and the analyzing of its operational performance, and increases the integrity and investment potentials of companies, and the rating of the companies before investors [14].

Accounting software apart from offering speedy processing operations, can also ensure accuracy of financial records by reducing or eliminating human errors in calculations, thus producing reliable information. The usefulness of computers to collect data, process the data and give out the information as output with minimal human interference through the use of accounting software capable of sorting classifying, calculating and summarizing the data to produce information further enhances the quality of accounting reports. Information systems processing and production processes in manufacturing companies are homogeneous, that businesses will lose customers who are dissatisfied if the information on product is not delivered on time and the product does not confirm to the needs (relevance) of customers $([6,18,19])$. Inaccurate or distorted information produced by computerized accounting system lead to disruption of operational process both in production and accounting functions and may attract huge maintenance costs and delay in reporting. If the operational information produce by accounting software is accurate, the firms will reap the benefit of reduction in waste, be efficient and be able to produce timely reports.([4, 36])

\subsubsection{Reliability}

Reliability as an attribute of accounting information shows the extent to which the information provided in financial reports is unbiased, free from error and faithfully represents that facts and numbers it purports to represent, and be able to provide information useful for economic decision making. Financial reporting reliability are based on some qualitative characteristics of financial reporting specified by conceptual framework and include; information having predictive value, confirmative value, completeness, neutrality, entity-specific, material being free from error and verifiability ([46, 33, 70]), The concept of reliability is a critical factor of quality of financial reporting which seeks to assure the users of financial reports that the information contained in the financial records represents the actual conditions, transactions and events of a reporting entity [2]. Companies are required to provide more unabridged disclosures associated with the underlying economic constructs, that the accounting information represents in order to assist users to better determine the reliability of reports. In line with the corporate objective of producing high quality report the adoption of accounting software provides better internal control report system at all times for use of decision makers [12].

\subsection{Theoretical Review}

\subsubsection{Systems Theory}

Computerized accounting Information System is the combination of software and hardware designed to collect, record and process financial information data, to produce information for decision makers ([51, 32]). Computerized accounting information system is a set of interrelated activities, documents, and technologies designed to collect and process data to give information to varied users. In accordance with the system theory a computerized accounting information system is a combination of many components or subsystems which relate and influence one another with the aim of achieving the holistic objective of the system. The system theory useful to study the working of phenomena with complex components and to understand the interaction between the components and how they influence each other [5].

The performance of the computerized accounting system largely depends on the functional capabilities of its components individually and as a system.

The general system theory as a set of elements standing in interrelation among themselves and with the environment [16]. The definition aptly points out that every system comprises of components that interrelate with themselves in performing their functions for the attainment of the entire system objective. Computerized accounting system are driven by software packages which are prepared taking into consideration accounting principles and procedures and business requirements in order to enable the system to perform the accounting functions automatically [32]. The software component of the accounting information system allows for the system automation. The automated feature of the computerized accounting system facilitates the ability of the system to perform many accounting related tasks effectively without human intervention [8].

The components of a computerized accounting system form the architectural framework of the system and represents its structural 
characteristics: the software architecture represents the logical organization of software into various elements meant to enhance the system performance and effectiveness [48]. Thus, the internal controls, automated data processing, relational database and automated reporting elements of the computerized accounting system are synthesized within supervisory framework of the accounting software, though with the involvement of other technological tools for effective performance [27].

\subsubsection{Technology Acceptance Theory}

Business have adopted the use of information system technology to become more competitive in controlling resource use, gain costs reduction advantage, and improve personnel efficiency in order to overcome global competitiveness. The acquisition and implementation of information system no matter how complex or simple, require users acceptance and confidence in order to subdue the reluctance of users in accepting new technology ([56, 57]). Thus there is the need to understand the issues that influence users decisions to adopt a particular system and to take them into consideration at the development stage of the system ([43, 57]) The need to have understanding of the users response to technology adoption led to the proposition of the technology acceptance model to explain how users deal with the adoption of new technologies [20].

The technology acceptance model is an information system theory developed in 1989, based on theory of reasoned action [52]. The theory posits that two factors influence the decision of people on whether to accept and use new technology. The two factors are perceived usefulness (PU), and perceived ease-of-use (PEOU) [20]. It is explained that the attitude of users of a technology is dependent on how the users perceived the usefulness of it to their work. Also, the perception of the user about the ease of use to accept the change in the use of the technology. The Technology Acceptance model has widely gained the attention and readiness of end users in the uses of the new technology and systems in many areas of applications [26].

The application at this theory to the use of accounting software will mean that when users of a software, perceives the software to be useful in enhancing their efficiency in the product of their tasks, they are more likely to accept the software, on the other hand, users may be reluctant to use a software, where it usefulness is in doubt. Furthermore, it is believed that where accounting software is easy to use, then users are more likely to use the software. Thus it is argued that the perceived usefulness of an accounting software and degree of complexity will influence the use of computerized accounting system.

\subsection{Empirical Review}

The challenges encountered with the use of traditional method of processing paved the way for computerized accounting information system $([64,45])$. The use of manual approaches by organization for capturing and recording accounting transactions is very time consuming and involves too much paper work [42], and often resulted in lack of fair financial data, which often led to improper decision making by management [15].
The key indicators determining the quality of financial information from the perspective of the developers of accounting standard are relevance and reliability which enhance the usefulness of information to decision makers [44].

A computerized accounting information processing is a total suit of components which comprises all inputs, storage, transactions, processing collecting and reporting of financial transaction data.

The study carried out to investigate the effect of accounting information system on organizational performance and the moderating effect of organizational culture in the relationship between accounting information system success factors and organizational performance in Jordan banking section. The study performance variable tested were service quality, quality of information, system quality and data quality. Primary data were used and analyzed with PLS SEM technique. Findings revealed that service quality, information quality and system quality are the significant accounting information system success factors for increasing organization performance. The result of the study also suggested that organizational culture influence performance by interaction with information quality, data quality and system quality $([1,9])$.

The adoption of information technology sophistication and management have positive linear relationship with the quality of, and economic feasibility of accounting information reports [28].

Conducted an examination of the effect of accounting information system on financial and non-financial measures of companies in Nigeria, using multiple linear regression to analyzed data revealed that accounting information system have positive significant effect on financial and non-financial measures indicators [37].

A study of impact of accounting information system on effectiveness of internal control and firm performance revealed that effective and efficient controls are effected through accounting software, which leads to better and reliable accounting information for better decision making for both internal and external users [59]. Just as several studies have found that the security, ease of use, and efficiency are the key features of information system quality and that information quality dimension includes accuracy, timeliness and completeness. Overall information quality and system quality have significant influences on accounting information system effectiveness, as the results of the study conducted to investigate the interrelationship among the quality measures of information system success including system quality, information quality and service quality that will influence accounting information effectiveness.

Their is a statistically significant positive effect on the nature and security of accounting information system on the quality of financial data in a study conducted to identify the effect of the use of accounting information system on the quality of financial data, which will have a cascading effect to enhance the quality of financial data which further improves reliability of accounting information [7].

The application of accounting software according to has 
enhanced the accounting information processing and is improving the reliability of transaction data entry, storage and preparation of financial statement and related information and is impacting the decision of users of the financial statement [64].

Accounting software enhances the quality of financial reporting through reliable and accurate data entry and improved data processing speed to generate credible information for good corporate governance [64].

Accounting software, allows for recording of large accounting transactions, reduction of manual and clerical tasks and generation of timely management information for decision making to the satisfaction of stakeholders and enhance the efficiency of accountants and assist them to satisfy the stakeholders services requirement $([4,13], 66])$.

Accounting information system allow for efficiency in recording accounting transactions, analyzing, monitoring and analyzing financial statement of any company, just as it helps organizations to prepare documents necessary for taxation purpose and generate information that support many other organizational tasks from the results of investigation conducted to determine the prospects and challenges of accounting software $([34,39])$, and in addition, the use of computerized accounting system speed up the job completion rate of users and enhances the quantity of the work done 65].

Studies have revealed that accounting and auditing firms that use information technology software have enhanced the quality of their accounting and auditing tasks [60].

\subsection{Conceptual Model of Interaction of Accounting Software and Corporate Reporting}

Independent Variable

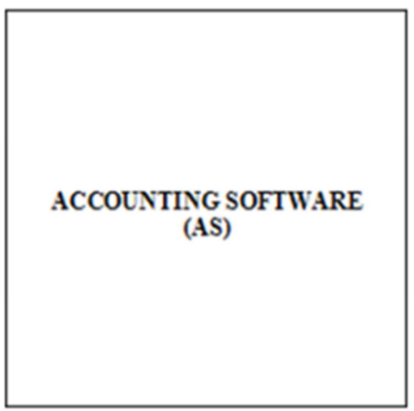

Dependent Variable
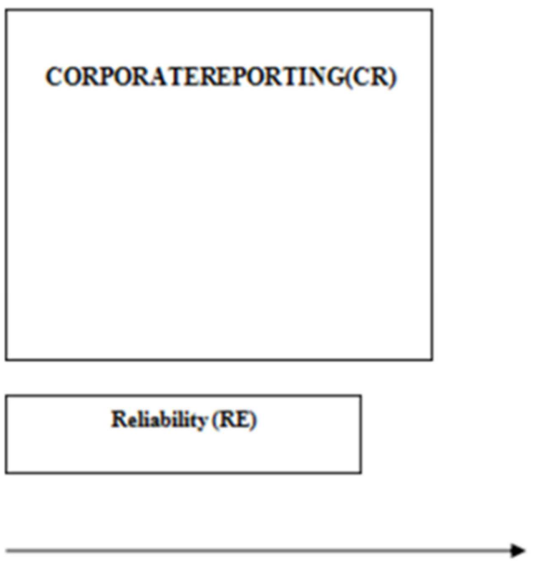

$\mathrm{H}_{\mathbf{0} 2}$

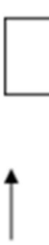

$\mathrm{Ho}_{2}$

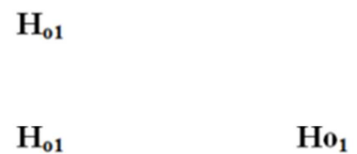




\section{Methodology}

The study adopted cross-sectional survey research design with the target population comprising 1517 SMEs who operates supermarkets in the city of Lagos. Cochran formula was employed to determine a sample size of 564. Stratified random sampling and proportionate techniques were used to group the sample to definite categories of managers and supervisors to ensure desired sample size in each stratum for adequate representation. A structured questionnaire was designed to collect primary data. The research instrument was validated and Cronbach's alpha reliability test showed coefficients of accounting software was 0.704 , while corporate reporting had a value of 0.896 .

Table 1. Decision Criteria.

\begin{tabular}{llll}
\hline & Hypothesis & Model & A priori Expectations if; \\
\hline 1 & $\mathrm{H}_{01}$ & $\mathrm{AS}=\alpha_{0}+\beta_{1} \mathrm{R}_{\mathrm{i}}+\mu_{\mathrm{i}}$ & $\mathrm{P} \leq 0.05: \beta_{1} \neq 0, \mathrm{H}_{01}$ will be rejected \\
2 & $\mathrm{H}_{02}$ & $\mathrm{AS}=\alpha_{0}+\beta_{2} \mathrm{~A}_{\mathrm{i}}+\mu_{\mathrm{i}}$ & $\mathrm{P} \leq 0.05: \beta_{2} \neq 0, \mathrm{H}_{02}$ will be rejected \\
\hline
\end{tabular}

Source: Researcher's Apriori Expectations

Where;

AS $=$ Accounting Software

$\mathrm{CR}=$ Corporate Reporting

$\mathrm{R}=$ Reliability

$\mathrm{A}=$ Accuracy

$\mu_{\mathrm{i}}=$ standard error

$\alpha=$ constant factor

$\beta=$ coefficient of beta

It is expected that accounting software usage in the selected supermarkets will positively affect corporate reporting by combined variables of reliability and accuracy. The two variables are considered critical in the ability of an entrepreneur to survive environmental turbulence in a computerized business environment.

\section{Results and Discussion}

\subsection{Data Analysis}

A total of 564 copies of questionnaire were administered out of which 493 were returned representing a response rate of
$87.4 \%$. This was considered adequate to draw conclusions on the study. Descriptive and inferential statistics were used for data analysis. Multiple regression analysis was used to statistically test the hypotheses.

Table 2 presents that out of four hundred and ninety three (493) sampled respondents in the supermarkets, majority $51.5 \%$ were managers. About forty one percent had second degree while majority (42.4\%) had experience of 11 years in the business. The result revealed that the respondents were well represented; professionally qualified, thus increasing the authenticity of the information supplied

Table 2. Respondents General Information.

\begin{tabular}{llll}
\hline Respondent's Position & Frequency & Percent & Cumulative percent \\
\hline Manager & 239 & 48.5 & 48.5 \\
Supervisor & 254 & 51.5 & 100.0 \\
Total & 493 & 100.0 & \\
Respondent's Educational Qualification & & & 40.0 \\
First Degree & 197 & 40.2 & 82.0 \\
Post graduate & 206 & 41.8 & 100.0 \\
Others & 90 & 18.0 & \\
Total & 493 & 100.0 & 25.6 \\
Respondent's experience in the business (years) & & & 57.6 \\
$1-4$ & 126 & 25.6 & 100.0 \\
$5-10$ & 158 & 32.0 & \\
11 years and above & 209 & 42.4 & 100.0 \\
Total & 493 & & \\
\hline
\end{tabular}

Source: Fieldwork, 2021

\subsubsection{Hypothesis Testing}

\section{Hypothesis 1}

According to Table 3 when tested to show whether accounting software has any effect on accuracy of corporate reporting of the selected supermarkets in Lagos state produced a coefficient of multiple correlation, an adjusted $\mathrm{R}^{2}=0.627$ at $\mathrm{p}=0.000<0.05$. It is therefore clear from hypothesis one that accounting software significantly and positively affect the reliability of corporate reporting of selected supermarkets in the city of Lagos $\left(\right.$ Adj. $R^{2}=0.627, F(3,485)=208.685, p<$ $0.05)$. The final regression model for this becomes: 
Table 3. Regression Coefficients of Accounting software on the reliability of corporate reporting.

\begin{tabular}{|c|c|c|c|c|c|c|c|c|}
\hline \multicolumn{9}{|c|}{ Coefficientsa } \\
\hline \multirow{2}{*}{\multicolumn{2}{|c|}{ Model }} & \multicolumn{2}{|c|}{ Unstandardized Coefficients } & \multirow{2}{*}{$\begin{array}{l}\text { Standardized Coefficients } \\
\text { Beta }\end{array}$} & \multirow{2}{*}{$\mathbf{T}$} & \multirow{2}{*}{ Sig. } & \multicolumn{2}{|c|}{ Collinearity Statistics } \\
\hline & & B & Std. Error & & & & Tolerance & VIF \\
\hline \multirow{2}{*}{1} & (Constant) & 72649.811 & 96893.829 & & .750 & .487 & & \\
\hline & Reliability & 5.566 & 1.307 & .834 & 4.257 & .008 & 0.563 & 3.193 \\
\hline
\end{tabular}

a. Dependent Variable: Corporate Reporting

$\mathrm{R}=0.594$, Adj. $\mathrm{R}^{2}=0.627, \mathrm{~F}(3,485)=208.685, \mathrm{p}=0.000<0.05$

Source: Researcher's Study (2021)

$$
\mathrm{AS}=72649.811+5.556(\mathrm{R})
$$

The apriori expectation is that if $\beta_{1} \neq 0$ and $p £ 0.05 \mathrm{H}_{01}$ should be rejected, otherwise it should be accepted. However, based on the result of the hypothesis, it was found that $\mathrm{p}=0.000<0.05$. We therefore conclude that accounting software have significant effect on the reliability of corporate reporting in the Lagos state. Thus, we reject the null hypothesis.

\subsubsection{Hypothesis 2}

Table 4. Regression Coefficients of Accounting software the accuracy of corporate reporting.

\begin{tabular}{|c|c|c|c|c|c|c|c|c|}
\hline \multicolumn{9}{|c|}{ Coefficientsa } \\
\hline \multirow{2}{*}{\multicolumn{2}{|c|}{ Model }} & \multicolumn{2}{|c|}{ Unstandardized Coefficients } & \multirow{2}{*}{$\begin{array}{l}\text { Standardized Coefficients } \\
\text { Beta }\end{array}$} & \multirow{2}{*}{$\mathbf{T}$} & \multirow{2}{*}{ Sig. } & \multicolumn{2}{|c|}{ Collinearity Statistics } \\
\hline & & B & Std. Error & & & & Tolerance & VIF \\
\hline \multirow{2}{*}{1} & (Constant) & 4.402 & 1.405 & & 3.132 & 0.002 & & \\
\hline & Accuracy & 0.261 & 0.094 & 0.155 & 2.779 & 0.006 & 0.395 & 2.530 \\
\hline
\end{tabular}

a. Dependent Variable: Corporate Reporting

$\mathrm{R}=0.629$, Adj. $\mathrm{R}^{2}=0.390, \mathrm{~F}(3,485)=80.180, \mathrm{p}=0.000<0.05$

Source: Researcher's Study (2021)

Table 3 shows the result of multiple regressions on whether accounting software significantly affect the accuracy of corporate reporting in selected supermarkets in Lagos state. The table shows that accounting software has positive and significant effect on accuracy of corporate reporting in the selected supermarkets with a coefficient of multiple correlation, an adjusted $\mathrm{R}^{2}=0.390$ at $\mathrm{p}=0.000<0.05$. The table further provides the coefficients of the regression model designed to investigate the effect of accounting software on corporate reporting. From the results, accuracy contribute significantly to corporate reporting of the selected supermarkets. The results show that unstandardized coefficients of accuracy $(\beta=0.261, p=0.002)$ is statistically significant. This implies that a unit increase in the accuracy of accounting software usage will have 0.261 increase in corporate reporting of the selected supermarkets.

The final regression model for thus becomes:

$$
\mathrm{AS}=4.402+0.261(\mathrm{~A})
$$

The apriori expectation is that if $\beta_{1} \neq 0$ and $\mathrm{p} £ 0.05 \mathrm{H}_{02}$ should be rejected, otherwise it should be accepted. However, based on the result of the hypothesis, it was found that $p=$ $0.000<0.05$. We therefore conclude that accounting software will significantly affect the accuracy of corporate reporting in the Lagos state. Thus, we reject the null hypothesis.

\subsection{Discussion of Findings}

The first hypothesis revealed accounting software positively and significantly affect the reliability of corporate reporting. By using accounting software businesses can enhance their corporate reporting performance. This finding is consistent with the study of [25] who established that accounting software system is reliable when information delivered on time and with error-free performance thus enhancing corporate reporting reliability, which in turn leads to better internal organizational efficiency. The study conducted by [8] in Jordan also revealed that Jordan International Investment Company has benefitted the most with accounting information system. [37] results is not an exception from previous studies where it was reported that accounting information system exert significant positive effect on financial and non-financial measures indicators of companies in Nigeria. Furthermore, studies have revealed that the use of accounting software generate better and reliable accounting information for manager in their decision making $([64,7,59])$.

The result of the second hypothesis showed that accounting software has significant and positive effect on the accuracy of corporate reporting among supermarket outlets in Lagos state. Firm will benefit from reduced labour costs and waste when the operational information from accounting software is highly accurate [55]. Accordingly, one of the important benefits of good accounting software is that it reduces human error that usually occurs during calculation and data entry. Inaccuracies in financial statements could lead to crises that may impact corporate reporting. The report on financial reporting quality in Atlanta, the United States as one of the developed country form opinion that the widespread failure in the financial information quality has created the need to improve on the accounting software [55].

The position is supported by a study that revealed that effective information technology improves timeliness and 
accounting of financial reporting [53]. while some studies also reveled that accounting sufferance reduces manual and clerical tasks information processing, thus leading to generation of a accurate information for decision makers $([13,18,46])$.

\section{Implication of the Study}

The results of hypotheses tested showed that the use of accounting software offers speed, accuracy, reliability and timeliness to accounting information processing, thus any investment on accounting software will enhance accounting processes of transactions data entry, storage processing and preparation of corporate report and other smart reports and its timely dissemination to stakeholders for decision making. This has the overall effect of the improving the corporate governance mechanism of an entity, this would boost the confidence of the stakeholders and possible improvement on the market efficiency of corporate organizations.

\section{Conclusion and Recommendations}

Technology has changed the face of the business world. Accounting software are designed for businesses to manage accounts and simplify financial operations in organizations. Accounting software makes it easier for business owners to manage financial procedures, performing financial tasks correctly and quickly thus enhancing corporate reporting in a computerized business environment. Based on the findings generated from data analysis, the study concluded that accounting software are effective in gathering and processing data and information to produce quality corporate report supermarkets outlets in Lagos state. Additionally, the findings showed that accounting software positively and significantly affect reliability and accuracy of corporate reporting in computerized business environment like that of supermarkets in Lagos state, Nigeria.

The accurate and reliable information in any business environment is very crucial to corporate reporting. Thus, to improve level of accounting software usage especially among firms in Nigeria, the software should be more user-friendly since it makes work easier for business owners to manage financial procedures, performing financial tasks correctly and quickly.

\section{References}

[1] Abdulrazak M (2013) The effect of Adopting International Financial Reporting Standard on Quality of Accounting Reports of Small and Medium in Enterprises in Naiobi Country. International Journal of Business and Management 2 (4).

[2] Adediran, S. A., Alade, S. O., \& Oshade, A. A. (2013). Reliability of Financial Reporting and Companies Attribute: The Nigerian experience. Research Journal of Finance and Accounting, 4 (16).

[3] Accounting Tools. (2020b). Types of Accounting Software. Retrieved from Accounting Tools: https://www.accountingtools.com/articles/types-of-acco untingsoftware.html

[4] Aggranni, R and Hassanah N, (2018) The Influence of Application Technology. Firms, Size and Strategy of Operating Performances of Micro, Small and Medium Enterprises Journal of Applied Science Research 14 (3).

[5] Ajzen, I (2006). Theory of Planned Behaviour. Retrieved $\begin{array}{llll}\text { November } & 29, & 2015 & \text { from }\end{array}$ http://www.people.umass.edu/aizen/tpb.diag.html

[6] Alabdullah, T. T. Y., Ahmed, E. R., \& Muneerali, M. (2019). Effect of Board Size and Duality on Corporate Social Responsibility: What has Improved in Corporate Governance in Asia?. Journal of Accounting Science, 3 (2), 121-135, DOI: https://doi.org/10.21070/jas.v3i2.2810

[7] Al-Dalabih, F. A. (2018). The Impact of the Use of Accounting Information Systems on the Quality of Financial Data. International Business Research, 11 (5). DOI: 10.5539/ibr.v11.

[8] Al-Dalaien, B., \& Khan, N. (2018). Effect of Accounting Information System on Financial Performance: A Study of Selected Real Estate Companies in Jordan. International Journal of Current Engineering and Scientific Research, (IJCESR), 4.

[9] Ali, B. J, Omar, W. A. W. and Baker. R 2016. The Critical Success Factors of Accounting Information System (AIS) and its Impact on Organizational Performance of Jordanian commercial banks international journals of economics, commerce and management United Kingdom IV (4).

[10] Anggraeni, A. F. (2016). Correlation between Information Technology and Management Information Systems Quality. International Journal of Scientific \& Technology Research, 5 (6).

[11] AR, S. (2020). Key Performance Indicators for Accounting Firms. Retrieved from QuickBooks: https://quickbooks.intuit.com/in/resources/accountants-a ndbookkeepers/key-performance indicators-for-accounting-firms/

[12] Arcega, C. K., Datinguinoo, E., Guerra, J., Guno, C., Mayuga, H. J., Villamena, E., \& Manongsong, J. L. (2015). Computerized vs. non-computerized Accounting System of Small and Medium Enterprises in LipaCity, Philippines: A Comparative Analysis. Asia Pacific Journal of Academic Research in Business Administration, 1 (1). http://research.lpubatangas.edu.ph/wp-content/uploads/2015/0 5/APJARB

[13] Azih, N. (2018), "Electronic accounting: an imperative tool for quality assurance in accounting education programme in the digital era", Nigerian Journal of Business Education (NIGJBED) Vol. 1 No. 2.

[14] Barako, D. Hancock, P., and Izan. It (2013) Relationship between Corporate Governance Attributes and Voluntary Disclosures in Annual Reports; The Kenyan Experience, Journal of Management and Business studies.

[15] Bashorun, M. T., Omopupa, K. T. and Dahiru, G. (2020), "Cloud computing and academic libraries in Nigeria", Handbook of Research on Digital Devices for Inclusivity and Engagement in Libraries, IGI Global.

[16] Bertalanffy, L. v. (1968). General systems theory: Foundations, development, applications. New York: George Braziller Inc. 
[17] Borhan, O. and Bader, O. (2018) Investigating t he impact of Accounting Information System on the Profitability of Jordanian Banks. Research Journal of Finance and Accounting 9 (18).

[18] Chong, Y., \& Nizam, I. (2018). The impact of accounting software on business performance. International Journal of Information System and Engineering, 6 (1). doi: 10.24924/ijise/2018.04/v6.iss1/01.26.

[19] Clikerman, P. M (1999) Improving Information quality. Internal Auditor 56 (3).

[20] Davis, F. D. (1989). Perceived Usefulness, Perceived Ease of Use, and User Acceptance of Information Technology. Management Information Systems Quarterly, 13 (3).

[21] Davoren, J. (2019). The three fundamental Roles of Information Systems in Business. Retrieved from Hearst Newspapers, LLC: Retrieved... from https://sm//businss.chron.com/three-foundamental-rolesinformation-system-business-23681.html

[22] Gajevszky, A (2015) Assessing Financial Reporting Quality: Evidence from Romania Audit Financial.

[23] Ganyam, A. I. and Ivungu, J. A. (2019), "Effect of Accounting Information System on Financial Performance of Firms: a Review of Literature", Journal of Business and Management, Vol. 21 No. 5.

[24] Gaynor, M., Andrea, S. K., Molly, M and Teri, L. Y (2016) Understanding the Relationship between Financial Reporting Quality and Audit Quality. Auditing: A Journal of practice \& theory 35 (4).

[25] Gorla, N. Somers, T. M and Wong, B (2010) Organizational Impact of System Quality, Information Quality, and Service Quality Journal of Strategics Information System 19 (3)

[26] Grant, R. A (2002) Contemporary strategy analysis, 4th Oxford Black well.

[27] Gupta, D., and Jain, M. (2017). Impact of Cloud Accounting on Business Performance. International Research Journal of Commerce, Arts and Science, 8 (12), 321-329.

[28] Haleem, A., and Raisal, I. (2016). The Study of the Influence of Information Technology Sophistication on the Quality of Accounting Information System in Bank Branches at Amapara 3 district, Sri Lanka. http://ir.lib.seu.ac.lk/handle/123456789/1944. Accessed 18 May 2020.

[29] Herath, S and Albarqi, N (2017) Financial Reporting Quality: A Literature Review: International Journal of Business Management and Commerce vol 2 no 2.

[30] Herbert, W. E, Ene, E. E and Tsegba, I. N (2013) Globalization of Financial Reporting Standards (IFRS). Adoption in Nigeria: Asian Journal of Business and Management Sciences vol. 3 No 12

[31] Horvat, T., \& Mojzer, J. (2019). Influence of Company Size on Accounting Information for Decision- Making of Management. Naše gospodarstvo/Our economy, 65 (2), 11-20, DOI: https://doi.org/10.2478/ngoe-2019-0007.

[32] Hurt, R. L. (2013). Accounting information systems: Basic concepts and current issues (3rd ed). New York, NY: McGraw-Hill/Irwin.
[33] IASB (2015) IASB work plan 2017-2021 Feedback statement on the (2015) agenda consultation, London international accounting standards Board (google scholar)

[34] Ibrahim, F., Ali, D. N. H. and Besar, N. S. A. (2020), "Accounting Information Systems (AIS) in SMEs: towards an integrated Framework", International Journal of Asian Business and Information Management (IJABIM), Vol. 11 No. 2.

[35] Intuit inc (2020) Twenty trends that will shape the next decade intuit 2020 report.

[36] Intuit Inc. (2018). QuickBooks small business user guide: Starting out with QuickBooks online. Intuit Australia.

[37] Ironkwe, U., \& Nwaiwu, J. (2018). Accounting Information System on Financial and Non-Financial Measures of Companies in Nigeria. International Journal of Advanced Academic Research | Business Development \& Management, 4 (2).

[38] Janvrim D. J and Watson, M. W. (2017) 'Big Data' A New Twist to Accounting Journal of Accounting Education. 38.

[39] Jinga, G, Dumitru, M., Dunitrana, $M$ and Vulpoi, $M$. (2010),'Accounting Systems for Cost Management used in the Romanian Economic entities; Accounting and Management information systems/contabilitate si information de Gestiune, Vol. 9 No. 2.

[40] Kapellas, k and siougle G (2017) Financial reporting practices and investment decisions $\mathrm{A}$ review of Literature. Industrial Engineering and Management 6 (4).

[41] Knapp, K. (2019), U.S. Patent No. 10,304,095, U.S. Patent and Trademark Office, Washington, DC.

[42] Kumar, P. N. (2020), "Technological Improvement in Accounting system through Cloud Computing", Our Heritage, Vol. 68 No. 5 .

[43] Mathieson K (1991) Predicting user Intentions: Comparing the Technology Acceptance model with the Theory of Planned Behavior. Information Systems Research 2 (3).

[44] Nwaobia, A. N., Kwarbai, J. D and Ajibade, A. T. (2016). Financial reporting quality on investors decisions. International Journal of Economics and Financial Research, 2 (7).

[45] Nyathi, K. A., Nyoni, T., Nyoni, M. and Bonga, W. G. (2018), The role of Accounting Information in the Success of Small and Medium Enterprises (SMEs) in "Zimbabwe: a case of Harare", Journal of Business and Management (DRJ-JBM), Vol. 1 No. 1.

[46] Ogundana, O., Ojeka, S., Ojua, M., \& Nwaze, C. (2017). Quality of Accounting Information and Information and Internal Audit Characteristic in Nigeria. Journal of Modern Accounting and Auditing, 13 (8).

[47] Ogundana, O., Okere, W., Ayomoto, O., Adesanmi, D., Ibidunni, S., \& Ogunleye, O. (2017). ICT and Accounting System of SMEs in Nigeria. Management Science Letters, 7 (1), 1-8, DOI: $10.5267 /$ j.msl.2016.11.007.

[48] Paganini, C. (2019). Primer: Understanding software and system architecture. Online: The New Stack. Retrieved 13 April 2020 from https://thenewstack.io/primer-understanding-software-and-syst em-architecture/ 
[49] Putra, Y. M. (2019). Analysis of Factors Affecting the Interests of SMEs Using Accounting Applications. Journal of Economics and Business, 2 (3), DOI: 10.31014/aior.1992.02.03.129.

[50] Ramosaji, B and Berisha, G (2014) Systems Theory and System Approach to Leadership. Iliria International Review, Kosoro and Felix-Verlas Germany vol 4.

[51] Romney, M. B. \& Steinbart, P. J. (2017). Accounting information systems. (Pearson Prentice Hall).

[52] Rotich E. C., (2017), The impact of accounting information systems on effectiveness of manufacturing in Kenya, Unpublished MBA Report from University of Nairobi.

[53] Sacer, I. M and Olnic A (2013) Information Technology and AIS Quality in Croatian Middle and Large Companies ‘ journal of information and organization society vol 37 (2).

[54] Shagari, S. L, Abdullah, A. Saat, R. Nigerian M (2017) Accounting information systems effectiveness: Evidence from Nigerian Banking Sector, Interdisciplinary Journal of information, knowledge, and management.

[55] Siriyama, K. H. (2017). Financial Reporting, Quality: a Literature Review. International Journal of Business Management and Commerce, 2 (2).

[56] Taherdoost H (2018) Development of an adoption model to assess user acceptance of e-service technology: E-Service Technology Acceptance Model. Behaviour \& Information Technology 37 (2).

[57] Taherdoost H, Sahibuddin S, N Jalaliyoon (2013) E-Services Usage Evaluation; Applications' level of Co-Creation and Digitalization. International Journal of Academic Research in Management 2 (1).

[58] Taiwo, J. N. (2016), "Effect of ICT on accounting information system and organisational performance: the application of information and communication Technology on Accounting Information System", European Journal of Business and Social Sciences, Vol. 5 No. 2.

[59] Teru, S. P., Idoko, I. F., \& Bello, L. (2019). The Impact of E-Accounting in Modern Businesses. International Journal of Accounting \& Finance Review, 4 (2), DOI: https://doi.org/10.46281/ijafr.v4i2.355.

[60] Thottoli, M. M., Thomas, K. V. and Ahmed, E. R. (2019), "Adoption of Audit Software by Audit Firms: a Qualitative Study", Journal of Information and Computational Science, Vol. 9 No. 9.
[61] Thottoli, M. M. (2020), "Impact of Accounting Software Among SMEs Accountants in Oman: Financial Markets", Institutions and Risks, Vol. 4 No. 2, pp. 25-33, doi: 10.21272/fmir.4(2).25-33.2020.

[62] Thottoli, M. M., Thomas, K. V. and Ahmed, E. R. (2019), "Adoption of Audit Software by Audit Firms: A Qualitative Study", Journal of Information and Computational Science, Vol 9 No. 9.

[63] Tilahun, M. (2019). A Review on Determinants of Accounting Information System Adoption. Science Journal of Business an Management, 7 (1), 17, DOI: 10.11648/j.sjbm.20190701.13.

[64] Turner, L., Weickgenannt, A. B. and Copeland, M. K. (2020), Accounting Information Systems: Controls and Processes, John Wiley \& Sons, Hoboken, New Jersey.

[65] Tychalas, D. and Karatza, H. (2020), “A Scheduling Algorithm for a fog Computing System with bag-oftasks Jobs: Simulation and Performance Evaluation", Simulation Modelling Practice and Theory, Vol. 98.

[66] Udegbunam, E. O., Uchenu, C. A., Odimmega, C. G., \& Nwogu, M. C. (2017). Electronic Accounting A Tool for Quality Management of Small and Medium Scale Enterprises (Smes) in the 21st Century Nigeria. Nigerian Journal of Business Education (NIGJBED), 5 (2), http://www.nigjbed.com.ng/index.php/nigjbed/article/view/24 4. Accessed 12 May 2020.

[67] Wickramasinghe, M., Cooray, N., Dissanayake, T., \& Pemarathna, R. (2017). Impact of Accounting Software for Business Performance. Imperial Journal of Interdisciplinary Research (IJIR) Vol-3, Issue-5, 2017 ISSN: 2454-1362, http://www.onlinejournal.in Imperial Journal of Interdisciplinary Research (IJIR), 3 (5). Retrieved from https://www.researchgate.net/publication/322117389_Im pact_of_accounting_software_for_Business_Performanc e

[68] Wilkinson J. W (2007) Accounting Information System Essential Concept and Application of Edition, John Willey \& Sons Inc, New York - USA.

[69] Xu, X (2020) "Application research of accounting archives informatization based on big data", Data Processing Techniques and Applications for Cyber-Physical Systems (DPTA 2019), Springer, Singapore.

[70] Yurisandi, T., \& Puspitasari, E. (2015). Financial Reporting Quality-Before and after IFRS Adoption using nice qualitative characteristics measurement. Procedia-Social Behavioral Sciences, 211. 